\title{
Influence of increment thickness on microhardness and bond strength in composite
}

\section{resins}

Influência da espessura do incremento na microdureza e resistência de união em resinas compostas

Influencia del incremento de espesor en la microdureza y la fuerza de unión en resinas compuestas

Received: 07/06/2021 | Reviewed: 07/15/2021 | Accept: 07/20/2021 | Published: 07/27/2021

Isis Almela Endo Hoshino

ORCID: https://orcid.org/ 0000-0001-8570-0425 Paulista State University “Júlio de Mesquita Filho", Brazil

E-mail: isis.hoshino@unesp.br

Mariana de Oliveira Bachega

ORCID: https://orcid.org/0000-0003-4966-779X Paulista State University "Júlio de Mesquita Filho", Brazil

E-mail: mariana.bachega@unesp.br

Paulo Henrique dos Santos

ORCID: https://orcid.org/0000-0002-4100-5153 Paulista State University "Júlio de Mesquita Filho", Brazil

E-mail: paulo.santos@unesp.br

André Luiz Briso

ORCID: https://orcid.org/0000-0002-6126-1760 Paulista State University "Júlio de Mesquita Filho", Brazil E-mail: andre.briso@unesp.br

Rodolfo Bruniera Anchieta

ORCID: https://orcid.org/ 0000-0002-7920-7885 Paulista State University “Júlio de Mesquita Filho”, Brazil E-mail: rodolfoanchieta2@hotmail.com

\begin{abstract}
The aim of this study was to evaluate the Knoop microhardness and the microtensile bond strength of a secondgeneration of bulk-fill (BF) and a nanohybrid composite resins (NH) in different thicknesses of increments. For this, ninety disks of composite resin were made for Knoop microhardness, being divided into six groups $(\mathrm{n}=15)$. The Knoop microhardness obtained in each millimeter of the internal face. For microtensile bond strength, ninety restored in third molars were used, divided into six groups $(\mathrm{n}=15)$. For Knoop microhardness, the Wilcoxon and Friedman test was used. For the microtensile bond strength were used the Two-way Anova test and Tukey's post-test $(\mathrm{p}<0.05)$. The NH resin showed higher Knoop micro hardness than BF and it was observed that hardness value decreases as increases the thickness of the resin. There was no significant difference in microtensile bond strength comparing $\mathrm{NH}$ and $\mathrm{BF}$. However, there was a significant difference between G2 and G4 for the NH groups, with the highest and lowest bond strength values, respectively. Thus, the new generation of the bulk-fill composite resin provided lower microhardness values as the thickness of the increments increases in comparison with the nanohybrid composite resin. The microtensile bond strength does not appear to have been influenced by the type of resin, or the thickness of the increment.
\end{abstract}

Keywords: Composite resins; Hardness tests; Polymerization.

\section{Resumo}

O objetivo deste estudo foi avaliar a microdureza Knoop e a resistência à microtração de uma segunda geração de bulkfill (BF) e uma resina composta nanohíbrida (NH) em diferentes espessuras de incrementos. Para tanto, noventa discos de resina composta foram confeccionados para microdureza Knoop, sendo divididos em seis grupos $(\mathrm{n}=15)$. A microdureza Knoop obtida em cada milímetro da face interna. Para a resistência de união à microtração, foram utilizados noventa restaurados em terceiros molares, divididos em seis grupos $(n=15)$. Para microdureza Knoop, foi utilizado o teste de Wilcoxon e Friedman. Para a resistência de união à microtração foram utilizados o teste Two-way Anova e o pós-teste de Tukey $(\mathrm{p}<0,05)$. A resina $\mathrm{NH}$ apresentou maior microdureza Knoop do que BF e observou-se que o valor de dureza diminui à medida que aumenta a espessura da resina. Não houve diferença significativa na resistência de união à microtração comparando NH e BF. Porém, houve diferença significativa entre $\mathrm{G} 2$ e G4 para os grupos NH, com maior e menor valor de resistência de união, respectivamente. Assim, a nova geração da resina composta bulk-fill proporcionou menores valores de microdureza à medida que a espessura dos incrementos aumenta em comparação com a resina composta nanohíbrida. A resistência de união à microtração não parece ter sido influenciada pelo tipo de resina ou pela espessura do incremento.

Palavras-chave: Resinas compostas; Testes de dureza; Polimerização. 


\section{Resumen}

El objetivo de este estudio fue evaluar la microdureza Knoop y la resistencia a la microtensión de un relleno masivo (BF) de segunda generación y una resina compuesta nanohíbrida $(\mathrm{NH})$ a diferentes espesores de incremento. Este es un estudio, se fabricaron noventa discos de resina compuesta para microdureza Knoop, divididos en seis grupos $(n=15)$. Microdureza Knoop obtenida en cada milímetro de la cara interior. Para la fuerza de unión microtensil, se utilizaron noventa terceros molares restaurados, divididos en seis grupos $(\mathrm{n}=15)$. Para la microdureza de Knoop se utilizó la prueba de Wilcoxon y Friedman. Para la fuerza de adherencia microtensil se utilizó la prueba de Anova de dos vías y la prueba posterior de Tukey ( $\mathrm{p}$ <0.05). La resina NH tenía una microdureza Knoop más alta que la BF y se observó que el valor de dureza disminuye a medida que aumenta el espesor de la resina. No hubo diferencia significativa en la fuerza de unión microtensil comparando NH y BF. Sin embargo, hubo una diferencia significativa entre G2 y G4 para los grupos $\mathrm{NH}$, con valores de fuerza de unión más altos y más bajos, respectivamente. Así, la nueva generación de resina compuesta de relleno masivo proporcionó valores de microdureza más bajos a medida que aumentaba el grosor del incremento en comparación con la resina compuesta nanohíbrida. La fuerza de la unión microtensil no parece haber sido influenciada por el tipo de resina o el espesor del incremento.

Palabras clave: Resinas compuestas; Pruebas de dureza; Polimerizacion.

\section{Introduction}

Nowadays, the conventional composite resins have many desirable characteristics that making it useful for use in anterior and posterior teeth, mainly because the ability to mimic tooth natural shades, the adhesion to enamel and dentin, the satisfactory mechanical properties and clinical longevity. Traditionally, the conventional resin composites are inserted using the incremental technique (Aggarwal et al., 2019).

Besides the above qualities, the incremental technique has some disadvantages, such as the possibility of contamination, the incorporation of bubbles between increments, as well as easier failures in marginal integrity, as well as the polymerization shrinkage (Kim, Kim, Choi, \& Lee, 2015). Thesissues are usually observed as the depth and extension of the cavity increases. In order to minimize or avoid the above negative effects conventional resin, the bulk-fill composite resins were developed (Chesterman, Jowett, Gallacher, \& Nixon, 2017; Kim et al., 2015).

The bulk -fill resins usually are inserted by means of a single thick increment of 4 to $6 \mathrm{~mm}$ thick. To make and effective light-cured and improve the depth of cure, manufacturers increased the translucency of this materials and added alternative photo-initiators, increasing the light absorption in deep restorations (Behery, El-Mowafy, El-Badrawy, Saleh, \& Nabih, 2016; Tauböck, Tarle, Marovic, \& Attin, 2015).

However, those modifications increase the translucence optical property in this new resin material which compromises the aesthetic factor when compared to conventional composite resins. To solve this problem, the aesthetic properties were improved in the second-generation bulk-fill resins, offering a material with optical characteristics similar to conventional composite resins. Information about this new material is scarce and the depth of cure, as well as the mechanical properties has been widely questioned (Sahadi et al., 2018; Yap, Eweis, \& Yahya, 2020).

With the new composition, it was an increase of resin opacity, and is expected lower light penetration beyond deep increments, resulting in lower degree of conversion of monomers to polymers. The objective of this study was to evaluate the Knoop microhardness, the curing depth and the microtensile bond strength of a second-generation of bulk-fill composite resin and nanohybrid resin in different thick of increments.

The null hypotheses tested were: (1) There would be no difference in Knoop microhardness for both composite resins;

(2) There would be no difference in the bond strength of the composite resins. 


\section{Methodology}

\subsection{Experimental design}

Two experimental factors were investigated in this study: restorative materials and the resin increment thickness. Restorative materials in 2 levels (Table 1): nanohybrid composite resin (Filtek Z350 XT — NH, 3M ESPE, Sumaré, SP, BR) and bulk-fill composite resin (Filtek One Bulk Fill-BF, 3M ESPE, Sumaré, SP, BR). The following thickness of the resin increment were proposed: 2, 3 and $4 \mathrm{~mm}$. Microhardness (NH) and microtensile bond strength were evaluated.

Table 1: Products (Material, Manufacturer and Composition) used in this study.

\begin{tabular}{|c|c|c|c|}
\hline Material & $\begin{array}{l}\text { Manufacturer/ } \\
\text { Batch nummber }\end{array}$ & Composition & Application \\
\hline $\begin{array}{l}\text { Filtek Z350XT } \\
\qquad(\mathrm{NH})\end{array}$ & $\begin{array}{c}\text { 3M ESPE } \\
\text { (Sumaré, SP, BR) } \\
772620\end{array}$ & $\begin{array}{l}\text { Organic matrix: Bis-GMA / Bis-EMA / UDMA / } \\
\text { TEG-DMA; } \\
\text { Filler: Combination of a non-agglomerated/non- } \\
\text { aggregated } 20 \mathrm{~nm} \text { silica filler, a non-agglomerated/ } \\
\text { non-aggregated } 4 \text { to } 11 \mathrm{~nm} \text { zirconia filler, an } \\
\text { aggregated zirconia/silica cluster filler (comprised of } \\
20 \mathrm{~nm} \text { silica and } 4 \text { to } 11 \mathrm{~nm} \text { zirconia particles); } 78.5 \\
\text { wt } \%, 66.3 \text { vol } \% \text {. } \\
\text { Photoinitiator: Camphorquinone }\end{array}$ & $\begin{array}{l}\text { Oblique increments of up to } 2 \mathrm{~mm} \\
\text { were inserted, until the desired } \\
\text { thickness was achieved. Each } \\
\text { increment was light cured for } 20 \mathrm{~s} \text {. }\end{array}$ \\
\hline $\begin{array}{l}\text { Filtek One Bulk Fill } \\
\text { Restorative } \\
\text { (BF) }\end{array}$ & $\begin{array}{c}\text { 3M ESPE } \\
\text { (Sumaré, } \mathrm{SP}, \mathrm{BR}) \\
\text { N933364 }\end{array}$ & $\begin{array}{l}\text { Organic matrix: AUDMA / UDMA / AFM / 1,12- } \\
\text { dodecane-DMA; } \\
\text { Fillers: Combination of a non-agglomerated/non- } \\
\text { aggregated } 20 \mathrm{~nm} \text { silica filler, a non-agglomerated/ } \\
\text { non-aggregated } 4 \text { to } 11 \mathrm{~nm} \text { zirconia filler, an } \\
\text { aggregated zirconia/silica cluster filler (comprised of } \\
20 \mathrm{~nm} \text { silica and } 4 \text { to } 11 \mathrm{~nm} \text { zirconia particles) and a } \\
\text { ytterbium trifluoride filler consisting of agglomerate } \\
100 \mathrm{~nm} \text { particles; } 76.5 \mathrm{wt} \%, 58.4 \mathrm{vol} \% \text {. } \\
\text { Photoinitiator: Camphorquinone }\end{array}$ & $\begin{array}{l}\text { A single increment was inserted in } \\
\text { the Teflon molds and light cured } \\
\text { for } 20 \mathrm{~s} \text {. }\end{array}$ \\
\hline
\end{tabular}

Bis-GMA bisphenol-A-glycidyl dimethacrylate, Bis-EMA ethoxylated bisphenol-A-dimethacrylate, UDMA urethane dimethacrylate, TEGDMA triethylene glycol dimethacrylate, AUDMA urethane aromatic dimethacrylate, / 1,12-dodecane-DMA 12-dodecane dimethacrylate, AFM Additional fragmentation molecules, wt $\%$ weight percentage, vol\% volume percentage. Source: Authors.

\subsection{Specimen preparation for the Knoop microhardness analysis}

Ninety disks of each material were made using a Teflon mold with internal dimensions of $4 \mathrm{~mm}$ diameter and 2, 3, or $4 \mathrm{~mm}$ thick) and divided into six groups $(\mathrm{n}=15)$, according to the type of composite resins and thick of the resin used. The NH was inserted by the incremental technique of $2 \mathrm{~mm}$ each increment and the $\mathrm{BF}$ in a single increment.

After the insertion of the composite resin corresponding to each study group, each specimen was covered by another polyester strip, pressed by a load to extrude excess material. The specimens were light-cured during $20 \mathrm{~s}$ with polywave LED (Valo Cordless, Ultradent, South Jordan, UT, USA). It was used in their standard mode keeping the tip surface closed to the specimen (Price, Dérand, Sedarous, Andreou, \& Loney, 2000). The light-curing unit was checked for consistency prior and after curing using a radiometer (RD-7 Radiometer, Ecel, Ribeirão Preto, SP, BR).

Immediately after light curing, the polyester strips were discarded and the specimens were kept in a dry, sealed, lightproof container in a water bath maintained at $37^{\circ} \mathrm{C}$ for $24 \mathrm{~h}$. Then, each specimen was sectioned in the transverse direction with a low-speed diamond saw under water cooling (Isomet 1000, Buheler, Lake Bluff, IL, USA). After, each specimen was then fixed on acrylic base and polished with \#600, 800, and 1200 grit silicon carbide paper (Buehler Inc., Lake Bluff, IL, USA) watercooled and a $1 \mu \mathrm{m}$ diamond suspension (Metadi, Buehler Inc., Lake Bluff, IL, USA) applied with cloth paper (Buehler Inc., 
Lake Bluff, IL, USA) for $60 \mathrm{~s}$ using a polishing machine. The specimens were cleaned in an ultrasonic cleaning device (Cristófoli, Campo Mourão, PR, Brazil) for 5 min after each disc and after the final polishing to remove surface residues.

\subsection{Knoop microhardness analysis}

The knoop microhardness test was carried out using a microdurometer (HMV, 2000 Shimadzu, Tokyo, TYO, Japan) with a Knoop diamond tip attached which was previously calibrated in a standard quartz specimen to verify the hardness modulus values.

The measurements in specimens were made from the internal composite surface of each half and center of the sample at distances of 10, 20,30,60,90, and $120 \mu \mathrm{m}$ from the top surface, using a Knoop indenter and a static load of $5 \mathrm{~g}$ applied for $10 \mathrm{~s}$. Two more series of indentations were performed on each sample, with $200 \mu \mathrm{m}$ located on the right and left of the indentations performed in the center of the discs. The knoop microhardness was determined for each millimeter of the sample (Briso et al., 2015).

\subsection{Curing depth analysis}

Based on the Knoop microhardness data, the curing depth in each sample was indirect measured. For each millimeter of the sample, the curing depth was calculated according to the formula below and expressed as a percentage (Garcia, Yaman, Dennison, \& Neiva, 2014).

$$
C D=\frac{B}{T}
$$

where $\mathrm{CD}$ is the curing depth, $\mathrm{B}$ is the microhardness of the millimeter to be analyzed and $\mathrm{T}$ is the microhardness of the most superficial layer.

\subsection{Specimens preparation for the Microtensile bond strength analysis}

The local Ethics Committee approved this study (\#126446). Ninety recently extracted healthy third molars, which were distributed in six study groups $(\mathrm{n}=15)$. The occlusal surfaces were grinded with $\# 600$ grit silicon carbide paper (Buheler, Lake Bluff, IL, USA) for exposure of the medium dentin.

A self-etching adhesive (Single Bond Universal, 3M ESPE, Sumaré, SP, BR) was actively applied for 20s and dried with an air jet for 5 seconds and light-cured during 20s with polywave LED (Valo Cordless, Ultradent, South Jordan, UT, USA). After, Teflon molds with a thick corresponding to each group $(2,3$, and $4 \mathrm{~mm})$ was used, and the restorative technique was performed as previously described.

All specimens were stored at $37^{\circ} \mathrm{C}$ in distilled water for 24 hours in light-protected containers. The 8 bonded sticks shaped specimens for the microtensile bond strength analysis were obtained through perpendicular cuts to the tooth/composite resin interface with a low speed diamond saw under water cooling (Isomet 1000, Buheler, Lake Bluff, IL, USA) in order to obtain specimens with a cross-sectional area of $1.0 \times 1.0 \mathrm{~mm}(+/-0.2 \mathrm{~mm}$ ), which were checked using a digital caliper (Mitutoyo Corporation, Tokyo, TYO, Japan).

\subsection{Microtensile bond strength analysis}

The average of the Knoop microhardness and microtensile bond strength values for each study group was calculated, and the results were subjected to the normality test (Shapiro - Wilk Test) $(\mathrm{p}<0.05)$. For the microhardness data which the distribution was non-normal, non-parametric tests were adopted (Mann-Whitney test) for comparison between composite resins. 
The Wilcoxon and Friedman tests were used to analyze the indentation of the increments. For microtensile bond strength, the variables showed normal distribution, therefore, ANOVA two factors repeated measures with Tukey's post-test $(\mathrm{p}<0.05)$ were performed. To assess the microtensile bond strength, each stick was fixed with "stubs" using cyanoacrylate glue and placed in the universal testing machine (Odeme Microtensile OM 100) at a speed of $0.7 \mathrm{~mm} / \mathrm{min}$ until fracture 13. The amount of load required for the fracture of each sticks was recorded in Newtons, and divided by the cross-sectional area of the sticks in $\mathrm{mm}^{2}$, so that the result is presented in MPa, as described in the formula:

$$
B S=\left(\frac{L}{4}\right)
$$

where $\mathrm{BS}=$ bond strength, $\mathrm{L}=$ load required to fracture the sample, and $\mathrm{A}=$ area of the bond interface in $\mathrm{mm}^{2}$.

The failure mode was evaluated for all fractured samples using stereo polarized light microscopy and bilateral lighting (Carl Zeiss, Oberkochen, GER) with a 40× magnification, in order to identify their mode fracture.

Fractures were classified as: A. Cohesive fracture in dentin; B. Adhesive fracture; C. Cohesive fracture in the composite resin; D. Mixed fracture (i.e. adhesive interface with cohesive involvement of dentin and/or composite resin).

Subsequently, some representative specimens from each group received a gold coating (Emitech K650, Emitech Products Inc., Houston, TX, United States) and were analyzed using scanning electron microscopy (SEM) (EVO LS-15, Carl Zeiss, Oberkochen, Germany) to characterize the dentin structure after the microtensile bond test.

\subsection{Statistical analysis}

The average of the Knoop microhardness and microtensile bond strength values for each study group was calculated, and the results were subjected to the normality test (Shapiro - Wilk Test) $(\mathrm{p}<0.05)$. For the microhardness data which the distribution was non-normal, non-parametric tests were adopted (Mann-Whitney test) for comparison between composite resins. The Wilcoxon and Friedman tests were used to analyze the indentation of the increments. For microtensile bond strength, the variables showed normal distribution, therefore, ANOVA two factors repeated measures with Tukey's post-test $(\mathrm{p}<0.05)$ were performed.

\section{Results}

\subsection{Microhardness}

The results of microhardness (Table 2) show that there was a significant difference between the depths of each thickness of both composite resins ( $\mathrm{p}<0.05$ ), except for the $2 \mathrm{~mm}$ groups. Groups of 2 and $3 \mathrm{~mm}$ of thickness exhibited the highest hardness values and significantly reduced as the thick of the increments and the depth of indentations in the specimen increased (Table 2). In specimens with $4 \mathrm{~mm}$, the first and second millimeters recorded higher hardness values; however they were statistically similar to each other ( $p>0.05$ ). The lowest hardness in depth was recorded at $4 \mathrm{~mm}$.

Similarly, when comparing the composite resins, it showed that the groups referring to the $\mathrm{NH}$ showed higher hardness values compared to $\mathrm{BF}(\mathrm{p}<0.05)$.

\subsection{Depth of cure}

The results of depth of cure are described in Table 2. It was observed that the first millimeter showed the best cure for the specimens of both resins and depths. However, the NH groups exhibited the highest depth of cure values and within the acceptable rate, except for the last millimeter of the $4 \mathrm{~mm}$ group (73.31\%).

Regarding BF resin, the values obtained were significantly lower compared to the $\mathrm{NH}$ groups. The last milimeters reached rates below acceptable level of the BF groups with $3 \mathrm{~mm}(3 \mathrm{rd}=76.77 \%)$ and $4 \mathrm{~mm}(3 \mathrm{rd}=77.56 \%$ and $4 \mathrm{th}=66.15 \%)$. 
When comparing the polishing periods for each composite resin, there was a significant difference only for micro-hybrid and nano-hybrid resins ( $\mathrm{p}$ <.05). Durafill VS recorded higher and lower values of roughness with late polishing in the period of 7 (G V) and 21 days (G IX), respectively. Spectra Smart showed a decrease in roughness between the polishing periods (immediate $>7$ days $>21$ days), with a difference only between the immediate and late polishing of 7 days with that of 21 days ( $\mathrm{p}$ <.05). For the nanoparticulate resins (Z 350 XT and Vittra APS) there was a similarity between the polishing periods.

Table 2 - Mean and standard deviation of Knoop microhardness and curing depth (\%), according to resins of different thick and position of indentation in depth.

\begin{tabular}{|c|c|c|c|c|c|c|c|}
\hline & & \multicolumn{3}{|c|}{$\mathrm{NH}$} & \multicolumn{3}{|c|}{$\mathrm{BF}$} \\
\hline & & Mean \pm SD & & $\%$ curing & Mean \pm SD & & $\%$ curing \\
\hline & $1^{\circ} \mathrm{mm}$ & $98,10 \pm 0,56$ & $\mathrm{~A} \mathrm{a}$ & $100 \%$ & $87,60 \pm 0,47$ & $\mathrm{Ab}$ & $100 \%$ \\
\hline \multirow[t]{2}{*}{$2 \mathrm{~mm}$} & $2^{\circ} \mathrm{mm}$ & $88,45 \pm 0,58$ & $\mathrm{~A} \mathrm{a}$ & $90,16 \%$ & $78,70 \pm 0,44$ & $\mathrm{Ab}$ & $89,84 \%$ \\
\hline & $1^{\circ} \mathrm{mm}$ & $95,95 \pm 0,50$ & A a & $100 \%$ & $85,58 \pm 0,45$ & $\mathrm{Ab}$ & $100 \%$ \\
\hline \multirow[t]{3}{*}{$3 \mathrm{~mm}$} & $2^{\circ} \mathrm{mm}$ & $87,50 \pm 0,40$ & $\mathrm{~B}$ a & $91,19 \%$ & $75,50 \pm 0,46$ & $\mathrm{~B} \mathrm{~b}$ & $88,22 \%$ \\
\hline & $3^{\circ} \mathrm{mm}$ & $79,95 \pm 0,59$ & $\mathrm{C} \mathrm{a}$ & $83,32 \%$ & $65,70 \pm 0,38$ & $\mathrm{Cb}$ & $76,77 \%$ \\
\hline & $1^{\circ} \mathrm{mm}$ & $94,75 \pm 0,48$ & $\mathrm{~A} \mathrm{a}$ & $100 \%$ & $82,50 \pm 0,30$ & $\mathrm{Ab}$ & $100 \%$ \\
\hline \multirow[t]{3}{*}{$4 \mathrm{~mm}$} & $2^{\circ} \mathrm{mm}$ & $85,60 \pm 0,50$ & $\mathrm{AB} a$ & $90,34 \%$ & $73,45 \pm 0,40$ & $\mathrm{AB} b$ & $89,03 \%$ \\
\hline & $3^{\circ} \mathrm{mm}$ & $77,40 \pm 0,48$ & $\mathrm{BC} \mathrm{a}$ & $81,68 \%$ & $63,99 \pm 0,38$ & $\mathrm{BC} \mathrm{b}$ & $77,56 \%$ \\
\hline & $4^{\circ} \mathrm{mm}$ & $69,50 \pm 0,48$ & $\mathrm{C} \mathrm{a}$ & $73,35 \%$ & $54,58 \pm 0,43$ & $\mathrm{Cb}$ & $66,15 \%$ \\
\hline
\end{tabular}

Different uppercase letters (within column) show difference between each indentation position in depth (eg NH2 $1^{\circ} \mathrm{mm}$ vs NH2 $2^{\circ} \mathrm{mm}$ ). Different lowercase letters (within row) compare $\mathrm{NH}$ and BF between milimemeters (e.g. NH2 $1^{\circ} \mathrm{mm}$ vs BF2 $1^{\circ} \mathrm{mm}$ ). Means followed by different letters are significantly different $(\mathrm{p}<0.05)$.

Source: Authors (2021).

\subsection{Microtensile bond strength}

Microtensile bond strength results is shown in Table 3, which statistical difference is observed only difference between the thickness increments of 2 and $4 \mathrm{~mm}$ for the NH groups (p <0.05), with the highest and lowest bond strength values, respectively. When comparing the composite resins (Table 3), there was a similarity between the thicknesses of the increments.

SEM examination revealed (Figures 1 and 2), the fracture mode found in the groups were predominantly adhesive and mixed fractures, except for BF 4mm, which mostly occurred cohesive fracture in the composite resin.

Table 3 - Means and standard deviation of $\mu$ TBS, according to resins of different thickness.

\begin{tabular}{ccccc}
\hline & \multicolumn{2}{c}{ NH } & \multicolumn{2}{c}{ BF } \\
& Mean \pm SD & & Mean \pm SD & \\
\hline $2 \mathrm{~mm}$ & $18,99 \pm 2,73$ & A a & $17,87 \pm 2,94$ & a \\
$3 \mathrm{~mm}$ & $17,66 \pm 2,32$ & AB a & $17,82 \pm 2,52$ & A a \\
$4 \mathrm{~mm}$ & $16,01 \pm 2,82$ & B a & $17,32 \pm 1,46$ & A a \\
\hline
\end{tabular}

Means followed by different letters. Uppercase letters (within column) compare millimeters in the same group and lowercase letters (within row) compare composite resins in each millimeter, are significantly different $(\mathrm{p}<0.05)$.

Source: Authors (2021). 
Figure 1 - Scanning electron microscopy images of failure modes (Cohesive fracture in the dentin, adhesive fracture, cohesive fracture in the composite resin and mixed fracture) for each composite resin (SEM ${ }^{\times} 20 \mu \mathrm{m}$ ): a-d. SEM for NH composite resin; e-h. SEM for BF composite resin.
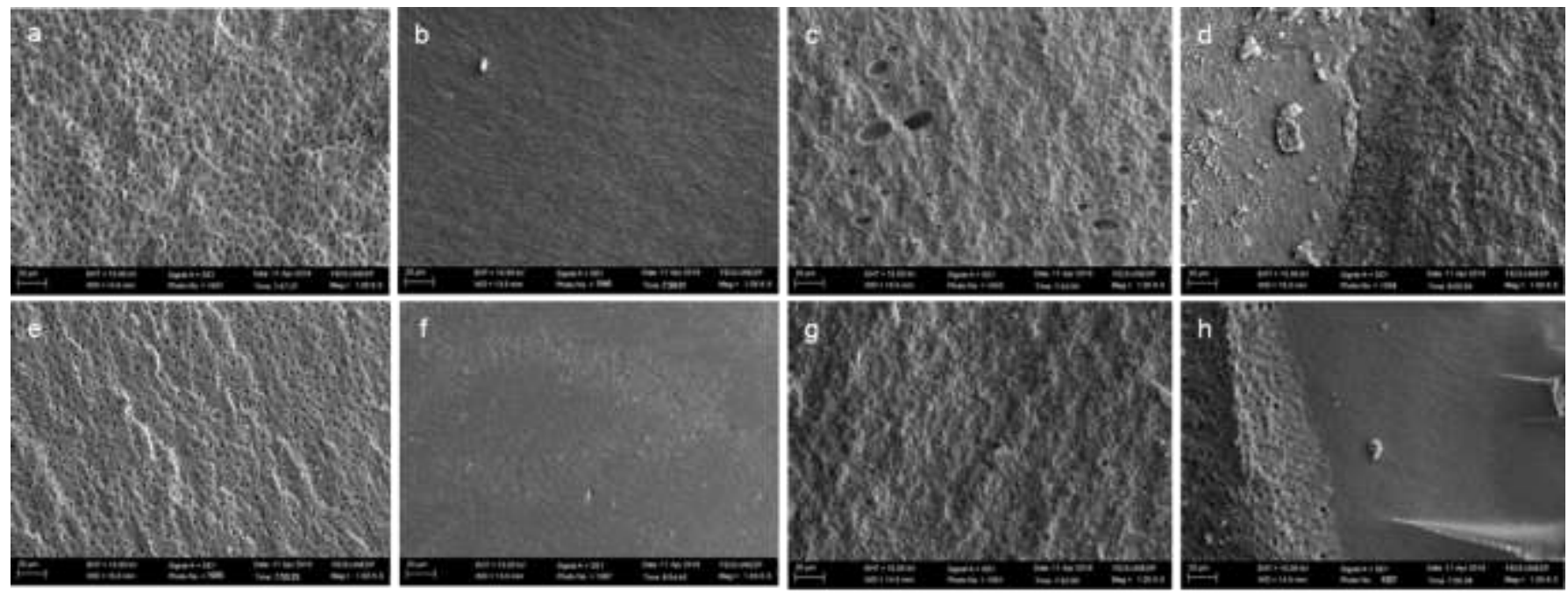

Source: Authors (2021).

Figure 2 - Failure mode analysis for each group (nanohybrid composite resin thick: G1- 2 mm, G2- 3 mm and G3- 4mm; bulk fill composite resin thick: G4- $2 \mathrm{~mm}$, G5- $3 \mathrm{~mm}$ and G6- $4 \mathrm{~mm}$ ). Failure modes: A. Cohesive fracture in the dentin, B. Adhesive fracture, C. Cohesive fracture in the composite resin, and D. Mixed fracture (i.e., adhesive interface with cohesive involvement of dentin and/or composite resin).

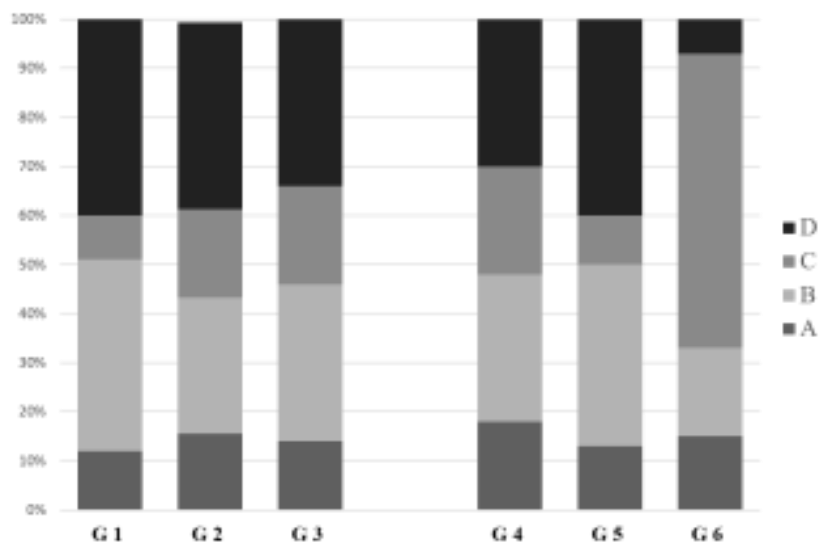

Source: Authors (2021).

\section{Discussion}

The present study compared the mechanical properties of Knoop microhardness and microtensile bond strength of nanohybrid and bulk fill composite resins. Knoop microhardness analysis has been used to evaluate the wear resistance of the material in the long term, as well as it to indicate the degree of conversion (Alzraikat, Burrow, Maghaireh, \& Taha, 2018). As it is an indirect measurement, the reduction in values as the depth increases may be related to the lower degree of conversion of the composites (Gajewski, Pfeifer, Fróes-Salgado, Boaro, \& Braga, 2012).

The first null hypothesis was rejected, since there was a difference of microhardness between the composites. Among the reasons that may have increased the microhardness of conventional resin can be mentioned the higher concentration of filler 
particles $(78.5 \mathrm{wt} \%, 66.3 \mathrm{vol} \%)$, which in bulk-fill resins are reduced in order to increase translucency $(76.5 \mathrm{wt} \%, 58.4 \mathrm{vol} \%)$ (Mandava et al., 2017; Warangkulkasemkit \& Pumpaluk, 2019), as well as the light-curing in each layer.

The difference in the curing depth was also observed in each composite light-cured, especially for thick increments of the bulk fill composite resin. These results could be explained looking for the bulk-fill photoinitiator and led device used in this study. The initiator canmphorquinone absorbs only blue light of wavelength of $460 \mathrm{~nm}$, and the led device used in this study emits two wavelengths. May be that the amount of light needed to activate the monomers in depth has not been sufficient for light cured in depth (Fronza et al., 2017). In addition, the 20s exposure time recommended by the manufacturer may not have been sufficient, as load concentrations and translucency of resins may require a longer time to promote greater conversion of monomers (Alkhudhairy, 2017; de Araújo, Schein, Zanchi, Rodrigues, \& Demarco, 2008).

Furthermore, the microhardness for thickness of $4 \mathrm{~mm}$ is in agreement with the literature for same type of composite resins (Gonçalves et al., 2018). Despite the observed reduction in microhardness, the degree of conversion rate was $80 \%$ of both resins are acceptable for both composite resins in the initial millimeters. A systematic review that evaluated the curing depth of bulk-fill resins concluded that this property is dependent on the material and the amount of light reaching the base of the composite and that the irradiance must be equal to or greater than $1.000 \mathrm{~mW} / \mathrm{cm}^{2}$ to reach acceptable rates (Lima, Troconis, Moreno, Murillo-Gómez, \& De Goes, 2018).

Although the bulk fill composite resin is used by the Bulk-fill technique with the insertion of increments of up to $4 \mathrm{~mm}$ in thickness, there was a difference in resistance to microtensile bond strength only between the NH composite resin thicknesses. Therefore, the second hypothesis was rejected. The results obtained are in agreement with Kumagai et al.(Kumagai, Zeidan, Rodrigues, Reis, \& Roulet, 2015), where it was observed that bulk fill composites present bond strength similarity compared to conventional resin.

This can be attributed to the modified composition of the bulk fill composite resin, consisting of monomers aromatic dimethacrylate (AUD-MA), additional fragmentation molecules (AFM), urethane dimethacrylate (UDMA) and 1,12-dodecane dimethacrylate (DDMA), reduce the polymerization of stress by shrinkage of up to 70\% (Lima et al., 2018), once the resin matrix reorganizes and adapts during light cured, as it presents greater flexibility and reactivity, thus reducing shrinkage without significant development of stress (Mandava et al., 2017).

Despite the microhardness of the composite resins in the 3rd and 4th millimeters differ, there was no predominance of cohesive fractures in the composite resin, except for the bulk fill composite resin with a thickness of $4 \mathrm{~mm}$. This suggests that the bond strength in the hybrid layer is still the weakest link in the adhesive interface (Piemjai, Chantarawej, \& Nakabayashi, 2020). Thus, even with less cure in the deeper layers, there was no influence on the bond strength and fracture pattern.

Although the results obtained in this study clarify important points about the mechanical properties of second-generation polymerization low shrinkage resins compared to a conventional composite resin, some limitations need to be taken into account. In this study, we did not evaluate the direct degree of conversion, nor did we simulate the conditions of $\mathrm{pH}$ and temperature variation found in the oral cavity. Thus, additional scientific evidence regarding this low polymerization shrinkage composite resin is needed before extrapolating its clinical applicability.

\section{Conclusion}

Within the limitations of this in vitro study, it was concluded that Bulk-fill microhardness decrease as the thickness of resin increment increase compared to nanohybrid composite resin. The microtensile bond strength does not appear to have been influenced by the type of composite resin, or by the thickness of the increment. 


\section{References}

Aggarwal, N., Jain, A., Gupta, H., Abrol, A., Singh, C., \& Rapgay, T. (2019). The comparative evaluation of depth of cure of bulk-fill composites - An in vitro study. J Conserv Dent, 22(4), 371-375. doi:10.4103/jcd.Jcd_453_18

Alkhudhairy, F. I. (2017). The effect of curing intensity on mechanical properties of different bulk-fill composite resins. Clin Cosmet Investig Dent, 9, 1-6. doi: $10.2147 /$ ccide.S130085

Alzraikat, H., Burrow, M. F., Maghaireh, G. A., \& Taha, N. A. (2018). Nanofilled Resin Composite Properties and Clinical Performance: A Review. Oper Dent, 43(4), E173-e190. doi:10.2341/17-208-t

Behery, H., El-Mowafy, O., El-Badrawy, W., Saleh, B., \& Nabih, S. (2016). Cuspal Deflection of Premolars Restored with Bulk-Fill Composite Resins. J Esthet Restor Dent, 28(2), 122-130. doi:10.1111/jerd.12188

Briso, A. L., Gonçalves, R. S., Costa, F. B., Gallinari Mde, O., Cintra, L. T., \& Santos, P. H. (2015). Demineralization and hydrogen peroxide penetration in teeth with incipient lesions. Braz Dent J, 26(2), 135-140. doi:10.1590/0103-6440201300225

Chesterman, J., Jowett, A., Gallacher, A., \& Nixon, P. (2017). Bulk-fill resin-based composite restorative materials: a review. Br Dent J, 222(5), 337-344. doi:10.1038/sj.bdj.2017.214

de Araújo, C. S., Schein, M. T., Zanchi, C. H., Rodrigues, S. A., Jr., \& Demarco, F. F. (2008). Composite resin microhardness: the influence of light curing method, composite shade, and depth of cure. J Contemp Dent Pract, 9(4), 43-50.

Fronza, B. M., Ayres, A., Pacheco, R. R., Rueggeberg, F. A., Dias, C., \& Giannini, M. (2017). Characterization of Inorganic Filler Content, Mechanical Properties, and Light Transmission of Bulk-fill Resin Composites. Oper Dent, 42(4), 445-455. doi:10.2341/16-024-1

Gajewski, V. E., Pfeifer, C. S., Fróes-Salgado, N. R., Boaro, L. C., \& Braga, R. R. (2012). Monomers used in resin composites: degree of conversion, mechanical properties and water sorption/solubility. Braz Dent J, 23(5), 508-514. doi:10.1590/s0103-64402012000500007

Garcia, D., Yaman, P., Dennison, J., \& Neiva, G. (2014). Polymerization shrinkage and depth of cure of bulk fill flowable composite resins. Oper Dent, 39(4), 441-448. doi:10.2341/12-484-1

Gonçalves, F., Campos, L. M. P., Rodrigues-Júnior, E. C., Costa, F. V., Marques, P. A., Francci, C. E., \& Boaro, L. C. C. (2018). A comparative study of bulkfill composites: degree of conversion, post-gel shrinkage and cytotoxicity. Braz Oral Res, 32, e17. doi:10.1590/1807-3107bor-2018.vol32.0017

Kim, R. J., Kim, Y. J., Choi, N. S., \& Lee, I. B. (2015). Polymerization shrinkage, modulus, and shrinkage stress related to tooth-restoration interfacial debonding in bulk-fill composites. J Dent, 43(4), 430-439. doi:10.1016/j.jdent.2015.02.002

Kumagai, R. Y., Zeidan, L. C., Rodrigues, J. A., Reis, A. F., \& Roulet, J. F. (2015). Bond Strength of a Flowable Bulk-fill Resin Composite in Class II MOD Cavities. J Adhes Dent, 17(5), 427-432. doi:10.3290/j.jad.a35012

Lima, R. B. W., Troconis, C. C. M., Moreno, M. B. P., Murillo-Gómez, F., \& De Goes, M. F. (2018). Depth of cure of bulk fill resin composites: A systematic review. J Esthet Restor Dent, 30(6), 492-501. doi:10.1111/jerd.12394

Mandava, J., Vegesna, D. P., Ravi, R., Boddeda, M. R., Uppalapati, L. V., \& Ghazanfaruddin, M. D. (2017). Microtensile bond strength of bulk-fill restorative composites to dentin. J Clin Exp Dent, 9(8), e1023-e1028. doi:10.4317/jced.53965

Piemjai, M., Chantarawej, P., \& Nakabayashi, N. (2020). Evaluation of Caries-Free Restorations Bonded with Various Adhesive Systems: In Vitro Study. Int J Dent, 2020, 5859835. doi:10.1155/2020/5859835

Price, R. B., Dérand, T., Sedarous, M., Andreou, P., \& Loney, R. W. (2000). Effect of distance on the power density from two light guides. J Esthet Dent, 12(6), 320-327. doi:10.1111/j.1708-8240.2000.tb00241.x

Sahadi, B. O., Price, R. B., André, C. B., Sebold, M., Bermejo, G. N., Palma-Dibb, R. G., \& Giannini, M. (2018). Multiple-peak and single-peak dental curing lights comparison on the wear resistance of bulk-fill composites. Braz Oral Res, 32, e122. doi:10.1590/1807-3107bor-2018.vol32.0122

Tauböck, T. T., Tarle, Z., Marovic, D., \& Attin, T. (2015). Pre-heating of high-viscosity bulk-fill resin composites: effects on shrinkage force and monomer conversion. J Dent, 43(11), 1358-1364. doi:10.1016/j.jdent.2015.07.014

Warangkulkasemkit, S., \& Pumpaluk, P. (2019). Comparison of physical properties of three commercial composite core build-up materials. Dent Mater J, 38(2), 177-181. doi:10.4012/dmj.2018-038

Yap, A. U., Eweis, A. H., \& Yahya, N. A. (2020). Dynamic Viscoelastic Characterization of Bulk-fill Resin-based Composites and Their Conventional Counterparts. Oper Dent, 45(2), 173-182. doi:10.2341/19-005-1 